\title{
Influence of mulching materials on growth and yield of strawberry (Fragaria ananassa duch.) cv. CAMAROSA under shadenet conditions of coastal Andhra Pradesh
}

\author{
S. Sujatha, V. Suchitra*, D.V. Swami, P. Subbaramamma, K. Uma Krishna and \\ L. Saravanan \\ Horticultural College and Research Institute, Dr. Y.S.R. Horticultural University, Venkataramannagudem, \\ WEST GODAVARI (A.P.) INDIA (Email : varakalasuchi3@gmail.com)
}

\begin{abstract}
Studies were carried out to evaluate the effect of different mulching materials on growth and yield of strawberry cv. CAMAROSA having eight treatments with three replications in Randomized Block Design duing the year 2015-2016. The treatments comprised of coconut husk, black polyethylene, paddy straw, card board sheets, dried banana leaves, paddy husk, silver polyethylene and no mulch (control). All the mulching treatments significantly contributed in improving the vegetative growth and yield of strawberry over unmulched plants. Paddy straw mulch gave the best results in terms of increasing plant spread (46.06 $\mathrm{cm}$ ), number of runners per plant (28.36), number of leaves per plant (42.56), leaf area per plant $\left(7621.08 \mathrm{~cm}^{2}\right)$, number of flowers per plant (61.66), number of days taken for fruiting (51.48 d), number of fruits per plant (35.46), fruit weight (5.00 g), fruit diameter (2.77 $\mathrm{cm}$ ) and fruit yield (5.82 tonnes per ha). Silver polythene mulch also performed well and showed at par result with that of paddy straw for all the parameters. Black polythene mulch showed the minimum values under hot and humid climate of Andhra Pradesh Thus mulch treatment with paddy straw was proved to be the best for cultivation of strawberry under shade net conditions for tropical regions especially coastal Andhra Pradesh conditions.
\end{abstract}

Key Words : Strawberry, Growth, Yield, Shadenet conditions, Tropical climate, Mulching

View Point Article : Sujatha, S., Suchitra, V., Swami, D.V., Subbaramamma, P., Uma Krishna, K. and Saravanan, L. (2018). Influence of mulching materials on growth and yield of strawberry (Fragaria ananassa duch.) cv. CAMAROSA under shadenet conditions of coastal Andhra Pradesh. Internat. J. agric. Sci., 14 (1) : 219-224, DOI:10.15740/HAS/IJAS/14.1/219-224.

Article History : Received : 18.09.2017; Revised : 06.12.2017; Accepted : 18.12.2017

\footnotetext{
* Author for correspondence:
} 